\begin{tabular}{|lcc|}
\hline & TOTOBUANG & \\
\hline Volume 7 & Nomor 1, Juni 2019 & Halaman 101-116 \\
\hline
\end{tabular}

\title{
PERILAKU BERBAHASA ANTARA KARYAWAN SUKU BUTON DAN SUKU BURU DI KOPERASI SERBA USAHA BURU JAZIRAH, NAMLEA \\ (The Language Behavior Between The Employee of Buton Tribe and Buru Tribe in Koperasi Serba Usaha Buru Jazirah, Namlea)
}

\author{
Nanik Indrayani \\ Universitas Iqra Buru \\ Jl. Prof. Dr. A. Bassalamah, No. 20, Namlea, Buru \\ Pos-el: nanikindra83@gmail.com
}

(Diterima: 27 April 2019; Direvisi: 24 Mei 2019; Disetujui: 3 Juni 2019)

\begin{abstract}
As good citizens, when we gather among fellow language users who have different regional languages, we must always use Indonesian as a language of unity. This study aims to describe how the language behavior between the employees of the Buton tribe and the Buru tribe at the Buru Jazirah Namlea Multipurpose Cooperative and how the language behavior barriers between Buton and Buru tribe employees at the Buru Jazirah Namlea Multipurpose Cooperative in Namlea Buru Maluku Regency. This qualitative descriptive study examines linguistic phenomena. The data source in this study is the utterances used between the employees of the Buton tribe and the Buru tribe in the Buru Jazirah Namlea Multipurpose Cooperative which contains the regional languages of the two tribes. The method of data collection is done through non-participant observation. While the technique of data collection is done through the technique of referring to skillful engagements, recording techniques, and note-taking techniques. The data that has been classified is then analyzed by qualitative descriptive analysis techniques. The results of this study revealed that the language behavior between the employees of the Buton tribe and the Buru tribe at the Buru Jazirah Namlea Multipurpose Cooperative was initially not very good considering they communicated with each other in their respective languages but over time this could be overcome so that between the Buton tribes and the Buru tribe cooperated well. Subsequent findings of language barriers between Buton and Buru tribes employees at the Buru Jazirah Namlea Multipurpose Cooperative influenced their respective regional languages, between the two tribes unable to understand each other because the two tribes used their respective regional languages. when interacting.
\end{abstract}

Keywords: Language Behavior, Buton Tribe and Buru Tribe, Cooperative

\section{Abstrak}

Sebagai warga negara yang baik, ketika kita berkumpul antara sesama pengguna bahasa yang saling berbeda bahasa daerah, kita harus selalu menggunakan bahasa Indonesia sebagai bahasa persatuan. Penelitian ini bertujuan mendeskripsikan bagaimana perilaku berbahasa antara karyawan suku Buton dan suku Buru di Koperasi Serba Usaha Buru Jazirah Namlea dan bagaimana hambatan-hambatan perilaku berbahasa antara karyawan suku Buton dan suku Buru di Koperasi Serba Usaha Buru Jazirah Namlea di Namlea Kabupaten Buru, Maluku. Penelitian deskriptif kualitatif ini mengkaji tentang fenomena kebahasaan. Sumber data dalam penelitian ini adalah tuturan-tuturan yang digunakan antara karyawan suku Buton dan suku Buru di Koperasi Serba Usaha Buru Jazirah Namlea yang mengandung bahasa daerah kedua suku tersebut. Metode pengumpulan data dilakukan melalui observasi nonpartisipasi. Sementara teknik pengumpulan data dilakukan melalui teknik simak bebas libat cakap, teknik rekam, dan teknik catat. Data yang sudah diklasifikasi kemudian dianalisis dengan teknik analisis deskriptif kualitatif. Hasil penelitian ini mengungkapkan bahwa perilaku berbahasa antara karyawan suku Buton dan suku Buru di Koperasi Serba Usaha Buru Jazirah Namlea pada awalnya kurang begitu baik mengingat mereka saling berkomunikasi dengan menggunakan bahasa daerah masing-masing, namun seiring dengan berjalannya waktu hal tersebut bisa teratasi sehingga antara suku Buton dan suku Buru terjalin kerja sama dengan baik. Temuan berikutnya hambatan-hambatan yang terjadi dalam perilaku berbahasa antara karyawan suku Buton dan suku Buru di Koperasi Serba Usaha Buru Jazirah Namlea yaitu pengaruh bahasa daerah masing-masing antara kedua suku tersebut tidak bisa saling memahami karena kedua suku tersebut menggunakan bahasa daerah mereka masing-masing ketika berinteraksi.

Kata-kata kunci: Perilaku Berbahasa, Suku Buton dan Suku Buru, Koperasi 


\section{PENDAHULUAN}

Komunikasi merupakan bagian yang sangat penting dalam seluruh aspek kehidupan manusia, hal ini terlihat dari setiap peristiwa, masa dan tempat yang selalu berhubungan dengan komunikasi. Komunikasi dapat dipahami maknanya melalui cara seseorang mengekspresikan dirinya dan orang lain dalam rangka mencapai tujuan yang diinginkan. Karena itu, komunikasi jelas tidak dapat dipisahkan dengan kehidupan manusia, baik sebagai individu maupun sebagai anggota masyarakat. Komunikasi sangat berhubungan dengan perilaku manusia untuk memenuhi kepuasan kebutuhannya. Hampir setiap orang membutuhkan hubungan sosial dengan orang lain, dan kebutuhan ini terpenuhi melalui pertukaran pesan yang berfungsi sebagai jembatan untuk mempersatukan manusia yang tanpa berkomunikasi akan terisolasi.

Komunikasi dan budaya adalah dua entitas tak terpisahkan, sebagaimana dikatakan Edward (dalam Mulyana, 2005:14). Budaya adalah komunikasi, dan komunikasi adalah budaya. Begitu kita mulai berbicara tentang komunikasi, tak terhindarkan, kita pun berbicara tentang budaya. Budaya dan komunikasi berinteraksi secara erat dan dinamis. Inti budaya adalah komunikasi karena budaya muncul melalui komunikasi.

Menurut (Liliweri 2003:9) komunikasi antarbudaya merupakan pertukaran pesan yang disampaikan secara lisan, tertulis, bahkan secara imajiner antara dua orang yang berbeda latar belakang budaya. Menurut (Mulyana dan Rakhmat, 2006:12) pesan-pesan itu dapat terlihat dari perilaku manusia tersebut. Perilaku individu merupakan hasil dari interaksi individu dengan lingkungannya. Penganut teori perilaku beranggapan bahwa individu ditentukan oleh dorongan eksternal atau lingkungan sekitarnya. Hal ini berarti bahwa individu dianggap sebagai makhluk pasif yang perilakunya terbentuk akibat pengaruh dari lingkungannya. Perilaku berbahasa adalah sikap mental seseorang dalam memilih dan menggunakan bahasa.

$\begin{array}{ccc}\begin{array}{c}\text { Salah } \\ \text { katu fungsi }\end{array} & \text { dalam } \\ \text { komunikasi } & \text { antarbudaya } & \text { adalah }\end{array}$ menghubungkan atau menjembatani perbedaan di antara kedua suku. Fungsi menjembatani itu dapat terkontrol melalui pesan-pesan yang mereka pertukarkan. Keduanya saling menjelaskan perbedaan tafsir atas sebuah pesan sehingga menghasilkan makna yang sama. Oleh karena itu, penting untuk mempelajari komunikasi antarbudaya untuk menghindari konflik berbeda budaya di lingkungan tempat kerja.

Kehidupan bermasyarakat Indonesia yang heterogen telah lama berlangsung, dan semestinya hubungan antarsuku berjalan harmonis dari waktu ke waktu. Namun, hingga sekarang kita masih sering melihat gesekan-gesekan antarsuku dikarenakan kurangnya komunikasi yang baik dalam menyikapi perbedaan dan menyelesaikan konflik. Menurut (Judhita, 2015 : 92) konflik-konflik tersebut menunjukkan bahwa interaksi antara dua suku berbeda dan laju pembangunan bangsa memperlihatkan porsi yang tidak seimbang. Fungsi komunikasi antarsuku juga tidak dilaksanakan dengan baik. Masing-masing cenderung bertahan dengan pAndangan sempit dan egoisme kesukuan mereka yang acap kali justru menimbulkan gesekan-gesekan yang berujung pada konflik kekerasan hingga kerusuhan, seperti konflik antara agama dan ras yang terjadi di Maluku tahun 1999 lalu.

Maluku terdiri atas ratusan suku yang dapat diindikasikan dari pengguna bahasa lokal, yang diketahui masih aktif dipergunakan sebanyak 117 dari jumlah bahasa lokal yang pernah ada. Masyarakat di daerah ini mencerminkan karakteristik yang multikultur, tetapi pada dasarnya memiliki kesamaan nilai budaya sebagai representasi kolektif. Salah satunya adalah filosofi Siwalima yang selama ini telah melembaga sebagai cara pAndang masyarakat tentang kehidupan bersama 
dalam kepelbagaian. Di dalam filosofi ini, terkandung berbagai pranata yang memiliki nlai umum dan dapat ditemukan di seluruh wilayah Maluku.

Maluku didominasi oleh ras suku bangsa Melania Pasifik, yang masih berkerabat dengan Fiji, Tonga, dan beberapa bangsa kepulauan yang tersebar di kepulauan Samudera Pasifik. Sementara itu, suku pendatang kebanyakan berasal dari daerah Buton, Makassar, Bugis, Cina dan Arab. Maluku juga memiliki ikatan tradisi dengan bangsa-bangsa kepulauan Pasifik seperti bahasa, lagu daerah, makanan, perangkat peralatan rumah tangga dan alat musik, (http://burukab.go.id/index.php/sejarah/ 11 Januari 2018 pukul 19.30 WIT).

Suku Buton telah hidup di Pulau Buru sejak 1970-an. Saat itu saja sekitar 15.000 orang Buton diperintahkan keluar dari sejumlah desa di Sulawesi Tenggara, atas instruksi aparat militer. Desa-desa mereka berjarak 10-an kilometer dari pelabuhan, tanpa bekal memadai, harus ditinggalkan. Orang Maluku aslinya memiliki darah Melanesia. Namun, sejarah panjang perdagangan dan pelayaran telah mengakibatkan tingkat tinggi kawin campur dalam darah keturunan di antara orang Maluku. Darah Bangsa Austronesia ditambahkan ke penduduk Melanesia asli pada sekitar 2000 SM. Fitur Melanesia yang terkuat terdapat di Kepulauan Kei, Kepulauan Aru, dan antara orang-orang di pedalaman kepulauan di Seram dan Buru.

Suku Buton dan suku Maluku yang bermukim di Pulau Buru memiliki hubungan yang erat dan baik, hanya saja perilaku berbahasa mereka yang berbeda. Namun, lebih dari itu suku Buton dan Maluku juga memiliki hubungan yang baik dalam bekerjasama contohnya yang terjadi di Kantor Koperasi Serba Usaha Buru Jazirah. Koperasi Serba Usaha ini mempunyai pemimpin yang berdarah Maluku tetapi memiliki sebagian besar karyawan berdarah Buton.
Koperasi Serba Usaha (KSU) Buru Jazirah adalah merupakan salah satu jenis usaha dalam bidang swasta yang bergerak dalam usaha simpan pinjam uang. Koperasi Serba Usaha Buru Jazirah adalah salah satu dari beberapa Koperasi yang ada di Namlea. Koperasi Serba Usaha (KSU) Buru Jazirah tidak memilah-milah dalam hal penerimaan karyawann sehingga, dalam Koperasi Serba Usaha (KSU) Buru Jazirah terdapat beberapa karyawan dari berbagai suku di antaranya suku Buru, Buton, Bugis, dan Jawa. Berdasarkan data yang diperoleh dari Kantor Pusat Koperasi Serba Usaha (KSU) Buru Jazirah, jumlah karyawan ada 60 orang karyawan dari berbagai suku yang telah disebutkan di atas, di antaranya suku Buru 15 orang, suku Buton 40, sisanya adalah suku Jawa dan Bugis. Berdasarkan jumlah keseluruhan karyawan, suku Buton termasuk yang paling banyak, sedangkan sisanya adalah suku Buru, Jawa, dan Bugis.

Jika dilihat dari perilaku berbahasa setiap suku yang berbeda jauh, jelas terlihat bahwa hubungan berbahasa antara warga suku Buton dan suku Buru terkadang tidaklah berjalan lancar. Contohnya, suku Buton selalu menggunakan bahasa Buton Cia-Cia atau bahasa Buton Selatan yaitu rumpun bahasa Austronesia yang dituturkan setiap hari oleh suku Buton, sedangkan bahasa Ambon atau bahasa sehari-hari suku Buru disebut dengan bahasa Melayu Dialek Ambon yang dipergunakan hampir oleh sebagian besar orang Maluku ini dalam komunikasi sehari-hari. Dalam berkomunikasi antara suku Buton dan suku Buru tidak bisa saling memahami apabila kedua suku tersebut menggunakan bahasa daerahnya masing-masing.

Berdasarkan latar belakang tersebut, peneliti tertarik untuk meneliti bagaimana komunikasi yang terjadi di lingkungan Kantor Koperasi Serba Usaha (KSU) antara karyawan suku Buton dan suku Buru, mengingat hubungan yang terjalin secara kekeluargaan selama 
bekerja. Hal ini menjadi penting juga karena berpengaruh terhadap pada efektivitas proses pekerjaan selama bekerja.

\section{LANDASAN TEORI \\ Sosiolinguistik \\ Pengertian Sosiolinguistik}

Menurut Nababan (1993:2)

sosiolinguistik berasal dari kata "sosio" dan "linguistic". Sosio sama dengan kata sosial yaitu berhubungan dengan masyarakat. Linguistik adalah ilmu yang mempelajari dan membicarakan bahasa khususnya unsur-unsur bahasa dan antara unsur- unsur itu. Jadi, sosiolinguistik adalah kajian yang menyusun teori-teori tentang hubungan masyarakat dengan bahasa. Berdasarkan pengertian sebelumnya, sosiolinguistik juga mempelajari dan membahas aspek-aspek kemasyarakatan bahasa khususnya perbedaan-perbedaan yang terdapat dalam bahasa yang berkaitan dengan faktorfaktor kemasyarakatan.

Seperti yang diungkapakan oleh Suwito (1983:2), sosiolingusitik menempatkan kedudukan bahasa dalam hubungannya dengan pemakaiannya dalam masyarakat. Ini berarti bahwa sosiolingusitik memAndang bahasa pertama-tama sebagai sistem sosial dan sistem komunikasi, serta merupakan bagian dari suatu masyarakat tertentu.

Sebagai objek dalam sosiolingusitik, bahasa dilihat sebagai sarana interaksi atau komunikasi di dalam masyarakat. Menurut Chaer dalam (Leonie Agustina 2004:3) sosiolinguistik adalah bidang ilmu antardisiplin yang memelajari bahasa dalam kaitannya dengan penggunaan bahasa itu di dalam masyarakat. Demikian juga menurut Nababan (1991:2), sosiolinguistik adalah studi atau pembahasan bahasa sehubungan dengan penutur bahasa itu sebagai anggota masyarakat, seorang penutur bahasa adalah anggota masyarakat-tutur atau lebih tepat sosiolinguistik itu memelajari atau mengkaji bahasa dan dimensi kemasyarakatan.

Fishman dalam (Chaer 2003:5) mengatakan kajian sosiolinguistik lebih bersifat kualitatif. Sosiolinguistik berhubungan dengan perincian-perincian penggunaan bahasa yang sebenarnya, seperti deskripsi pola-pola pemakaian bahasa atau dialek tertentu yang dilakukan penutur, topik, latar pembicaraan.

Sosiolinguistik memAndang bahasa pertama-tama sebagai sistem sosial dan sistem komunikasi serta bagian dari masyarakat dan kebudayaan tertentu. Sedangkan yang dimaksud dengan pemakaian bahasa adalah bentuk interaksi sosial yang terjadi dalam situasi konkret. Berdasarkan beberapa uraian di atas dapat disimpulkan bahwa sosiolinguistik berarti ilmu yang mempelajari tentang bahasa yang digunakan dalam daerah tertentu atau dialek tertentu. Sosiolinguistik cenderung memfokuskan diri pada kelompok sosial serta variabel linguistik yang digunakan dalam kelompok itu sambil berusaha mengorelasikan variabel tersebut dengan unit-unit demografik tradisional pada ilmuilmu sosial, yaitu umur, jenis kelamin, kelas sosio-ekonomi, pengelompokan regional, status, dan lain-lain. Bahkan, pada akhir-akhir ini juga diusahakan korelasi antara bentuk-bentuk linguistik dan fungsi- fungsi sosial dalam interaksi intra-kelompok untuk tingkat mikronya, serta korelasi antara pemilihan bahasa dan fungsi sosialnya dalam skala besar untuk tingkat makronya, Ibrahim (1995:4). Dari uraian di atas dapat disimpulkan bahwa sosiolinguistik adalah ilmu yang mempelajari tentang bahasa yang memfokuskan diri pada kelompok sosial serta variabel linguistik.

Menurut Chaer (2003:2), linguistik adalah bidang ilmu yang mempelajari tentang bahasa atau ilmu yang mengambil bahasa sebagai objek kajian. Dengan demikian, dapat dikatakan bahwa sosiolinguistik adalah bidang ilmu antardisipliner yang mempelajari bahasa dalam kaitannya dengan penggunaan 
bahasa itu dalam masyarakat. Dari uraian di atas dapat disimpulkan bahwa sosiolinguistik adalah antardisipliner yang mempelajari bahasa dalam kaitannya dengan bahasa yang digunakan dalam lingkungan tersebut.

Berdasarkan beberapa pendapat di atas dapat disimpulkan bahwa sosiolinguistik tidak hanya mempelajari tentang bahasa tetapi juga mempelajari tentang aspek-aspek bahasa yang digunakan oleh masyarakat. Sosiolinguistik merupakan ilmu antardisiplin antara sosiologi dengan linguistik, dua bidang ilmu empiris yang mempunyai kaitan erat. Sosiologi merupakan kajian yang objektif dan ilmiah mengenai manusia di dalam masyarakat, lembaga-lembaga, dan proses sosial yang ada di dalam masyarakat. Sosiologi berusaha mengetahui bagaimana masyarakat itu terjadi, berlangsung, dan tetap ada. Dengan mempelajari lembagalembaga, proses sosial dan segala masalah sosial di dalam masyarakat, akan diketahui cara-cara manusia menyesuaikan diri dengan lingkungannya, bagaimana mereka bersosialisasi, dan menempatkan diri dalam tempatnya masing-masing di dalam masyarakat.

\section{Konsep Dasar Komunikasi}

Istilah komunikasi berpangkal pada perkataan Latin Communis, yang artinya membuat kebersamaan atau membangun kebersamaan antara dua orang atau lebih. Komunikasi juga berasal dari akar kata dalam bahasa Latin Communico ang artinya membagi Cherr dalam (Cangara, 2012:20). Dalam kehidupan sehari-hari, takpeduli di mana Anda berada, Anda selalu berinteraksi dan berkomunikasi dengan orang-orang tertentu yang berasal dari kelompok, ras, etnik, suku atau budaya lain. Berkomunikasi dengan orangorang yang berbeda kebudayaan, merupakan pengalaman baru yang selalu dihadapi.

Esensi komunikasi terletak pada proses, yakni suatu aktivitas yang "melelayani" hubungan antara pengirim dan penerima pesan melampaui ruangan dan waktu. Komunikasi merupakan pusat dari seluruh sikap, perilaku, dan tindakan yang terampil dari manusia. Manusia tidak dapat dikatakan berinteraksi sosial kalau dia tidak berkomunikasi dengan cara atau melalui pertukaran informasi, ide-ide, gagasan, maksud serta emosi yang dinyatakan dalam simbol-simbol dengan orang lain. Komunikasi terjadi setiap saat. Manusia tidak bisa meninggalkan proses komunikasi dalam hidupnya. Manusia selalu melakukan penyampaian dan penerimaan pesan tiap waktu, dengan tujuan berbeda di dalamnya. Baik itu hanya sekadar menyampaikan pesan untuk diterima dan dipahami sehingga bertujuan untuk mempengaruhi lawan bicaranya agar mengikuti kehendak si pembicara.

Kesamaan bahasa yang digunakan dalam percakapan antara komunikator (pemberi pesan) dan komunikan (penerima pesan) tidak dapat menjamin berhasilnya suatu proses komunikasi. Bahasa yang digunakan antara keduanya boleh jadi dimaknai beda oleh si komunikan. Proses komunikasi bisa dikatakan efektif bila keduanya, komunikator dan komunikan, dapat mengerti bahasa dan mampu memaknai pesan yang disampaikan.

Definisi yang lebih luas diajukan oleh Steven dalam (Cangara, 2012:21) sebagai berikut: Komunikasi terjadi kapan saja suatu organisme memberi reaksi terhadap suatu objek atau stimulisasi. Apakah itu berasal dari seseorang atau lingkungan sekitarnya. Misalnya seorang berlindung pada suatu tempat karena diserang badai, atau kedipan mata sebagai reaksi terhadap sinar lampu, juga adalah peristiwa komunikasi. Memahami komunikasi lebih dalam, Rogers dalam (Cangara, 2012:22) mengatakan bahwa komunikasi adalah proses suatu ide dialihkan dari sumber kepada satu penerima atau lebih, dengan maksud untuk mengubah tingkah laku mereka. Definisi ini kemudian dikembangkan oleh Rogers bersama Kincaid dalam (Cangara, 
2012:22) bahwa: Komunikasi adalah suatu proses dua orang atau lebih membentuk atau melakukan pertukaran informasi dengan satu sama lainnya, yang pada gilirannya akan tiba pada saling pengertian yang mendalam.

\section{Komunikasi Antarbudaya}

Menurut Dood,1991:5 dalam (Liliweri 2003:11) komunikasi antarbudaya meliputi komunikasi yang melibatkan peserta komunikasi yang mewakili pribadi, antarpribadi, kelompok, dengan tekanan pada perbedaan latar belakang kebudayaan yang mempengaruhi perilaku komunikasi para peserta.

Proses komunikasi dan kebudayaan berkenaan dengan komunikasi antarbudaya. Ciri yang menAndai komunikasi antarbudaya adalah sumber dan penerimanya berasal dari budaya yang berbeda. Oleh karena itu, seseorang dapat dikatakan telah mempelajari budaya orang lain ketika ia telah berkomunikasi dengan orang lain tersebut. Rich dan Ogawa "Intercultural communication (komunikasi antarbudaya) adalah komunikasi antara orang-orang yag berbeda kebudayaan, misalnya antarsuku bangsa, antaretnik dan ras, antarkelas sosial (Samovar dan Porter, $1976: 25$ ).

Menurut Dood dalam (Liliweri, 2002 : 11) komunikasi dan kebudayaan tidak sekadar dua kata tetapi dua konsep yang tidak dapat dipisahkan. Komunikasi antarbudaya adalah komunikasi yang melibatkan peserta komunikasi yang mewakili pribadi, antarpribadi, dan kelompok, dengan tekanan pada perbedaan latar belakang kebudayaan yang mempengaruhi perilaku komunikasi para peserta. Kita dapat melihat bahwa proses perhatian komunikasi dan kebudayaan terletak pada variasi langkah dan cara berkomunikasi yang melintasi komunitas atau kelompok manusia. Fokus perhatian studi komunikasi dan kebudayaan juga meliputi bagaimana menjajaki makna, pola-pola tindakan, juga tentang bagaimana makna dan pola-pola itu diartikulasikan ke dalam sebuah kelompok sosial, kelompok budaya, kelompok politik, proses pendidikan, bahkan lingkungan teknologi yang melibatkan interaksi manusia.

Berbicara mengenai komunikasi antarbudaya, ada beberapa asumsi yang berkaitan, yaitu :

1) Komunikasi antarbudaya dimulai dengan anggapan dasar bahwa ada perbedaan persepsi antara komunikator dengan komunikan.

2) Dalam komunikasi antarbudaya terkandung isi dan relasi antarpribadi.

3) Gaya personal mempengaruhi komunikasi antarpribadi.

4) Komunikasi antarbudaya bertujuan mengurangi tingkat ketidakpastian.

5) Komunikasi berpusat pada kebudayaan.

6) Efektifitas antarbudaya merupakan tujuan komunikasi antarbudaya.

Tampak sekali bahwa komunikasi antarbudaya lebih menekankan aspek utama yakni komunikasi antarpribadi di antara komunikator dan komunikan yang kebudayaannya berbeda.

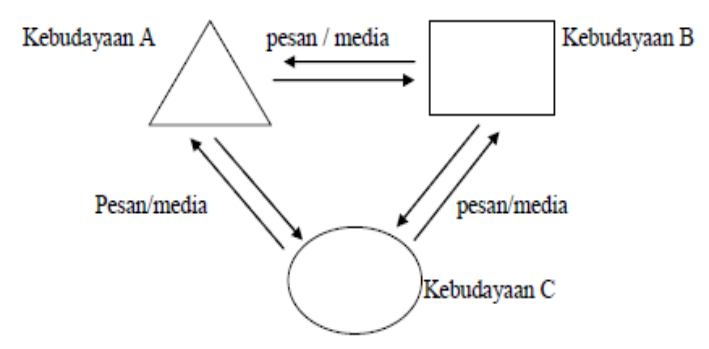

Gambar 2.1

Model Komunikasi Antarbudaya (Liliweri, 2002 : 13)

\section{Unsur-unsur Komunikasi Antarbudaya}

Unsur-unsur yang membentuk terjadinya komunikasi saling berkaitan satu sama lain untuk menciptakan komunikasi yang efektif. Unsur-unsur tersebut adalah:

a) Sumber, semua peristiwa komunikasi akan melibatkan sumber sebagai pembuat atau pengirim informasi. 
Sumber sering disebut pengirim, komunikator atau dalam bahasa Inggris disebut source, sender, atau encoder.

b) Pesan, yang dimaksud dalam proses komunikasi adalah sesuatu yang disampaikan pengirim kepada penerima. Dalam bahasa Inggris pesan biasanya diterjemahkan dengan kata message, content, atau information.

c) Media, yang dimaksud di sini ialah alat yang digunakan untuk memindahkan pesan dari sumber kepada penerima. Selain indra manusia, ada juga saluran komunikasi seperti telepon, surat, telegram yang digolongkan sebagai media komunikasi antarpribadi.

d) Penerima, adalah pihak yang menjadi sasaran pesan yang dikirim oleh sumber. Penerima bisa disebut dengan berbagai macam istilah seperti khalayak, sasaran, komunikan atau dalam bahasa Inggris disebut audience atau receiver. Penerima adalah elemen terpenting dalam proses komunikasi, karena dialah yang menjadi sasaran dari komunikasi.

e) Pengaruh atau efek adalah perbedaan antara apa yang dipikirkan, dirasakan, dan dilakukan oleh penerima sebelum dan sesudah menerima pesan.

f) Tanggapan balik, ada yang beranggapan umpan balik sebenarnya adalah salah satu bentuk daripada pengaruh yang berasal dari penerima.

g) Lingkungan, situasi adalah faktorfaktor tertentu yang dapat memengaruhi jalannya komunikasi. Faktor ini dapat digolongkan menjadi empat macam, yakni lingkungan fisik, lingkungan sosial budaya, lingkungan psikologis, dan dimensi waktu.

\section{Hakikat Kebudayaan}

Budaya adalah suatu cara hidup yang berkembang dan dimiliki bersama oleh sebuah kelompok orang dan diwariskan dari generasi ke generasi. Budaya terbentuk dari banyak unsur yang rumit, termasuk sistem agama dan politik, adat istiadat, bahasa, perkakas, pakaian, bangunan, dan karya seni. Bahasa sebagaimana juga budaya merupakan bagian tak terpisahkan dari diri manusia sehingga banyak orang cenderung menganggapnya diwariskan secara genetis. Beberapa konsep yang berkaitan dengan kebudayaan dalam membahas komunikasi antarbudaya adalah sebagai berikut :

a. Budaya Dominan, sebuah kebudayaan yang sangat menonjol dalam suatu masyarakat sehinga tampilan kebudayaan itu seolah-olah berada "di atas" atau "menguasai" kebudayaan lain, kebudayaan itu seolah-olah "mengatur" seluruh aspek kehidupan dalam suatu masyarakat.

b. Common Culture, suatu sistem pertukaran simbol-simbol yang sama, makna atas simbol tersebut dipahami oleh dua pihak melalui sebuah proses persetujuan.

c. Sub Kultur, suatu kelompok atau sub unit budaya yang berkembang ketika adanya kebutuhan sekelompok orang untuk memecahkan sebuah masalah berdasarkan pengalaman bersama.

d. Cultural Lag, konsep ini diperkenalkan oleh William Oghburn untuk menggambarkan proses sosial, budaya dan perubahan teknologi. Perubahan sosial cenderung dinilai "ketinggalan" dari perubahan teknologi. Cultural lag dihasilkan tatkala sebuah institusi sosial-budaya gagal mengadaptasi fungsi-fungsi mereka ke dalam bagianbagian dari sistem sosial-budaya mereka yang luas.

e. Culture Shock kekacauan budaya yang dalam perspektif sosial merupakan hasil dari konfrontasi suatu masyarakat terhadap kebudayaan baru yang 
mendadak masuk dan mengganggu kebudayaan mereka.

f. Kebudayaan tradisional perilaku yang merupakan kebiasaan atau cara berpikir dari suatu kelompok sosial yang ditampilkan melalui-tidak saja adat istiadat tertentu tetapi juga perilaku adat istiadat yang diharapkan oleh anggota masyarakatnya.

g. Multikultural konsep untuk menggambarkan pelbagai aktivitas yang didorong oleh beberapa maksud, seperti hadirnya pengakuan atas kebudayaan dari pelbagai etnik dan ras.

Pembahasan komunikasi antarbudaya hampir pasti melibatkan beberapa konsep atau mungkin istilah yang berulang-ulang. Konsep-konsep itu misalnya komunikasi, budaya, komunikasi antarbudaya, komunikasi lintas budaya, etnik dan ras, etnosentrisme, dan multikultural.

\section{Perilaku Komunikasi}

Dalam kebanyakan peristiwa komunikasi yang berlangsung, hampir selalu melibatkan penggunaan lambanglambang verbal dan nonverbal secara bersama-sama. Lambang-lambang nonverbal juga dapat berfungsi kontradiktif, pengulangan, bahkan pengganti ungkapan-ungkapan verbal, misalnya ketika seseorang mengatakan terima kasih (bahasa verbal) maka orang tersebut akan melengkapinya dengan tersenyum (bahasa nonverbal), seseorang setuju dengan pesan yang disampaikan orang lain dengan anggukan kepala (bahasa nonverbal). Dua komunikasi tersebut merupakan contoh bahwa bahasa verbal dan nonverbal bekerja bersamasama dalam menciptakan makna suatu perilaku komunikasi.

A. Perilaku Verbal dalam Komunikasi Antarbudaya

Perilaku verbal sebenarnya adalah komunikasi verbal yang biasa kita lakukan sehari-hari. Simbol atau pesan verbal adalah semua jenis simbol yang menggunakan kata-kata atau lebih.
Hampir semua rangsangan wicara yang kita sadari termasuk ke dalam kategori pesan disengaja, yaitu usaha-usaha yang dilakukan secara sadar untuk berhubungan dengan orang lain secara lisan. Suatu sistem kode verbal disebut bahasa. Bahasa dapat didefinisikan sebagai perangkat simbol, dengan aturan untuk mengkombinasikan simbolsimbol tersebut yang digunakan dan dipahami suatu komunitas. Bahasa memiliki banyak fungsi, namun sekurang-kurangnya ada tiga fungsi yang erat hubungannya dalam menciptakan komunikasi yang efektif. Ketiga fungsi itu adalah:

1. Untuk mempelajari tentang dunia sekeliling kita;

2. Untuk membina hubungan yang baik di antara sesama manusia;

3. Untuk menciptakan ikatanikatan dalam kehidupan manusia;

Menurut Ohoiwutun, dalam berkomunikasi antarbudaya ada beberapa hal yang harus diperhatikan yaitu:

a. Kapan orang berbicara, jika kita berkomunikasi antarbudaya perlu diperhatikan ada kebiasaan (habits) budaya yang mengajarkan kepatutan kapan seorang harus atau boleh berbicara.

b. Kecepatan dan jeda berbicara, masing-masing daerah memiliki perbedaan kecepatan ketika berbicara. Agar masing-masing pihak bisa mengerti dengan kalimat yang ingin kita sampaikan, ada baiknya untuk berbicara dengan kecepatan normal dan memberikan jeda di akhir setiap kalimat.

c. Hal memperhatikan, konsep ini berkaitan erat dengan gaze atau pAndangan mata yang diperkenankan waktu berbicara 
bersama-sama. Dalam

berkomunikasi

"memperhatikan" adalah

melihat bukan sekadar

mendengarkan. Sebaliknya

orang Jawa tidak mementingkan

"melihat" tetapi mendengarkan.

Anda membayangkan jika seorang Jawa sedang berbicara dengan orang Timor yang terus menerus menatap mata orang Jawa, maka si Jawa merasa tidak enak dan bahkan menilai orang Timor itu sangat kurang ajar. Sebaliknya orang Timor merasa dilecehkan karena si Jawa tidak melihat dia waktu memberikan pengarahan.

d. Masalah intonasi cukup berpengaruh dalam berbagai bahasa yang berbeda budaya. Orang kadang di Lembata/Flores memakai kata bua berarti melahirkan namun kata yang sama kalau ditekan pada huruf akhir "ae-bua" (atau buaq), berarti berlayar; kata laha berarti marah tetapi kalau disebut tekanan di akhir ,a $\mathrm{a}^{\mathrm{ee}}$ lahaq merupakan maki yang merujuk pada alat kelamin lakilaki.

e. Gaya kaku atau puitis, (Ohoiwutun, 1997:105) menulis bahwa jika Anda membandingkan Bahasa Indonesia yang digunakan pada awal berdirinya negara ini dengan gaya yang dipakai dewasa ini, dekade 90-an maka Anda akan dapati bahwa bahasa Indonesia tahun 1950-an lebih kaku. Gaya bahasa sekarang lebih dinamis lebih banyak kata dan frase dengan makna gAnda, tergantung dari konteksnya. Perbedaan ini terjadi sebagai akibat perkembangan bahasa. Tahun 1950-an bahasa Indonesia hanya dipengaruhi secara dominan oleh bahasa Melayu.

Dewasa ini puluhan bahasa daerah, teristimewa bahasa Jawa dengan puluhan juta penutur aslinya, telah ikut mempengaruhi formula berbahasa Indonesia.

f. Bahasa tidak langsung, setiap bahasa mengajarkan kepada para penuturnya mekanisme untuk menyatakan sesuatu secara langsung atau tidak langsung.

B. Perilaku Nonverbal dalam Komunikasi Antarbudaya Manusia dalam berkomunikasi selain memakai kode verbal (bahasa) juga memakai kode nonverbal. Kode nonverbal biasa disebut bahasa isyarat atau bahasa diam (silent language). Hal menarik dari kode nonverbal adalah studi Albert Maharabian yang menyimpulkan bahwa tingkat kepercayaan dari pembicaraan orang hanya 7 persen berasal dari bahasa verbal, 38 persen dari vocal suara, dan 55 persen dari ekspresi muka. Ia juga menambahkan bahwa jika terjadi pertentangan antara apa yang diucapkan sesorang dengan perbuatannya orang lain cenderung memercayai hal-hal yang bersifat nonverbal. Menurut Matusov dalam (Liliweri, 2003 :139) komunikasi nonverbal merujuk pada variasi bentukbentuk komunikasi yang meliputi bahasa. Menurut Simon Capper dalam (Liliweri, 2003:140) setidaknya ada lima kategori fungsi pesan nonverbal:

a. Fungsi Regulasi (Regulation Function), fungsi regulasi menjelaskan bahwa simbol nonverbal yang digunakan mengisyaratkan bahwa proses komunikasi verbal sudah berakhir. Dalam percakapan dengan sesama, Anda akan mengalami 
kesulitan menyatakan diri, atau memberikan reaksi balik (feedback).

b. Fungsi Interpersonal (Interpersonal Function), fungsi ini membantu kita untuk menyatakan sikap dan emosi dalam relasi antarpribadi (bisa di sebut pula dengan 'affect displays').

c. Fungsi Emblematis (Emblematic Function), fungsi ini menerangkan bahwa pesan nonverbal dapat disampaikan melalui isyaratisyarat gerakan anggota tubuh, terutama tangan. Contohnya ketika menyatakan kemenangan, Anda membuat huruf "V" pada jari tengah dan jari telunjuk.

d. Fungsi Ilustrasi (Illustrative Function), fungsi ilustrasi menerangkan bahwa pesan nonverbal digunakan untuk mengindikasikan ukuran, bentuk, jarak, dan lain-lain. Contoh ketika Anda sedang memberikan pengarahan kepada orang lain untuk menunjuk suatu obyek, apakah besar-kecil, dekat-jauh, tinggi-rendah.

b. Fungsi Adaptasi (Adaptive Function), fungsi adaptif dimaksudkan sebagai fungsi pesan nonverbal untuk menyesuaikan berbagai pesan balik verbal maupun nonverbal. Misalnya, Anda menciptakan jenis-jenis tanda atau simbol yang menyenangkan diri sendiri. Kadang-kadang tanda-tanda itu lakukan secara tidak sadar. Gerakan refleks seperti memegang jenggot, mencabut kumis, mengurai rambut, menggigit kuku, mencubit jerawat termasuk dalam kategori fungsi adaptasi.

\section{METODE}

Penelitian ini merupakan penelitian deskriptif kualitatif yang mengkaji fenomena kebahasaan. Penelitian kualitatif dengan menggunakan metode deskriptif adalah penelitian yang memaparkan, menganalisis, mengklasifikasi data yang telah diperoleh, yang dilakukan sematamata berdasarkan pada fakta-fakta yang ada atau fenomena yang terjadi secara nyata atau empirik, Sudaryanto (1992:62).

Menurut Sudaryanto (1990:36), populasi sebagai jumlah keseluruhan pemakaian bahasa tertentu yang tidak diketahui batas-batasnya akibat dari banyaknya orang yang memakai (dari ribuan sampai jutaan), lamanya pemakaian (di sepanjang hidup penutur-penuturnya), dan luasnya daerah serta lingkungan pemakaian.

Penentuan sampel dalam penelitian ini dilakukan dengan cara purposif. Purposif itu sendiri merupakan teknik penentuan sampel dengan pertimbangan tertentu yang dipilih secara sengaja sesuai kebutuhan dalam membahas atau menganalisis permasalahan mengingat waktu yang ada dan kemampuan penulis. Sutopo (2002:36) mengatakan bahwa pilihan sampel diarahkan pada sumber data yang dipandang memiliki data penting yang berkaitan dengan permasalahan yang sedang diteliti.

Menurut Muhammad (2011:200) penyediaan data mewakili tiga kegiatan; mengumpulkan, memilih, dan menata. Metode penyediaan data ini diberi nama metode simak, Mahsun (2005:93-94). Metode simak adalah metode yang digunakan untuk memperoleh data dengan melakukan penyimakan terhadap penggunaan bahasa.

Tuturan-tuturan yang disimak dan diamati tersebut, dikhususkan pada tuturan yang mengandung hambatan-hambatan atau faktor penyebab perilaku berbahasa antara karyawan suku Buton dan suku Buru ketika sedang istirahat untuk makan siang, serta didokumentasikan untuk diinventarisasikan sebagai data dalam penelitian ini. Adapun teknik-teknik yang digunakan untuk melengkapi metode simak tersebut antara lain. 


\section{Teknik Simak Bebas Libat Cakap}

Dalam teknik ini, peneliti hanya berperan sebagai pengamat pengguna bahasa oleh para informan dalam hal ini seluruh karyawan Koperasi Serba Usaha Buru Jazirah ketika sedang istirahat untuk makan siang. Peneliti tidak terlibat langsung dalam peristiwa pertuturan yang tuturannya sedang diteliti. Peneliti hanya menyimak tuturan yang terjadi antara karyawan suku Buton dan suku Buru di Kantor Koperasi Serba Usaha Buru Jazirah ketika sedang istirahat untuk makan siang.

\section{Teknik Rekam}

Teknik rekam ini merupakan teknik lanjutan dari teknik simak bebas libat cakap. Semua tuturan yang berupa percakapan yang terjadi ketika sedang istirahat untuk makan siang direkam menggunakan Tape Recorder. Percakapan atau tuturan tersebut selanjutnya ditranskripsikan dalam bentuk teks (tulisan) untuk dianalisis.

\section{Teknik Catat}

Teknik catat ini merupakan lanjutan dari teknik simak bebas libat cakap dan teknik rekam. Semua data yang direkam kemudian dicatat dengan menggunakan alat tulis manual. Selanjutnya, data yang dicatat diketik dengan menggunakan komputer.

Analisis data merupakan upaya yang dilakukan untuk mengelompokkan data. Menurut Subroto (2007:59), bahwa menganalisis berarti mengurai atau memisahkan data untuk disatukan sesuai dengan jenisnya. Dalam penguraian tersebut langkah-langkah yang diterapkan sebagai berikut:

\section{Identifikasi Data}

Semua tuturan yang berupa percakapan seluruh karyawan Koperasi Serba
Usaha Buru Jazirah ketika sedang istirahat untuk makan siang yang mengandung faktor-faktor atau hambatan-hambatan dalam perilaku berbahasa tersebut.

2. Klasifikasi Data

Data-data yang sudah diidentifikasi sebelumnya, diklasifikasikan berdasarkan permasalahan yang ada, faktor-faktor atau hambatan-hambatan dalam perilaku berbahasa terjadi ketika sedang istirahat untuk makan siang.

3. Analisis Data

Data yang sudah diklasifikasi, kemudian dianalisis dengan mendeskripsikan secara terperinici permasalahan yang terdapat dalam data yang telah dikumpulkan berdasarkan teori yang berkaitan dengan perilaku berbahasa antara suku Buton dan suku Maluku, sebagai dasar dalam pedoman menganalisa. Dalam menganalisis data, peneliti menemukan perilaku berbahasa antara karyawan suku Buton dan suku Buru di Koperasi Serba Usaha Buru Jazirah Namlea adalah 10 percakapan dalam bentuk kata, 5 percakapan dalam bentuk frasa, dan 5 dalam bentuk kalimat.

\section{PEMBAHASAN}

Pada bagian ini akan dipaparkan informasi tentang informan dari suku Buton dan suku Buru yang bekerja di Kantor Koperasi Serba Usaha Buru Jazirah Namlea dan berdomisili lebih dari 5 tahun. Hal ini bertujuan untuk mengetahui perbedaan, dan kesamaan dalam masingmasing informan. Dengan mengetahui persamaan, dan perbedaan masing-masing informan, maka dapat diketahui relevansi antara suku Buton dan suku Buru.

Suku Buton adalah suku bangsa yang menempati wilayah Sulawesi Tenggara tepatnya di Kepulauan Buton. Suku Buton juga dapat ditemui dengan jumlah yang signifikan di luar Sulawesi Tenggara Seperti di Maluku Utara, Kalimantan Timur, Maluku, dan Papua. Seperti suku-suku di Sulawesi 
kebanyakan, suku Buton juga merupakan suku pelaut.

Orang-orang Buton sejak lama merantau ke seluruh pelosok nusantara dengan menggunakan perahu berukuran kecil yang hanya dapat menampung lima orang, hingga perahu besar yang dapat memuat barang sekitar 150 ton. Secara umum, orang Buton adalah masyarakat yang mendiami wilayah kekuasaan kesultanan Buton. Daerah-daerah itu kini telah menjadi beberapa kabupaten dan kota di Sulawesi Tenggara di antaranya Kota Baubau, Kabupaten Buton, Kabupaten Buton Selatan, Kabupaten Buton Tengah, Kabupaten Buton Utara, Kabupaten Wakatobi, Kabupaten Bombana, Kabupaten Muna, dan Kabupaten Muna Barat.

Selain merupakan masyarakat pelaut, masyarakat Buton juga sejak zaman dulu sudah mengenal pertanian. Komoditas yang ditanam antara lain padi ladang, jagung, singkong, ubi jalar, kapas, kelapa, sirih, nanas, pisang, dan segala kebutuhan hidup mereka sehari-hari. Orang Buton terkenal pula dengan peradabannya yang tinggi dan hingga saat ini peninggalannya masih dapat dilihat di wilayah-wilayah Kesultanan Buton, di antaranya benteng keraton Buton yang merupakan benteng terbesar di dunia, istana Malige yang merupakan rumah adat tradisional Buton yang berdiri kokoh setinggi empat tingkat tanpa menggunakan sebatang paku pun, mata uang Kesultanan Buton yang bernama Kampua (http://www.wacananusantara.org/sukubuton/diakses 26 Januari 2018 pukul 20.00).

Orang-orang suku Maluku umumnya memiliki kulit gelap, rambut ikal, kerangka tulang besar dan kuat. Profil tubuh mereka lebih atletis dibandingkan dengan suku lain di Indonesia dikarenakan aktifitas utama mereka merupakan aktifitas laut seperti berlayar dan bernenang.

Maluku didominasi oleh ras suku bangsa Melania Pasifik, yang masih berkerabat dengan Fiji, Tonga, dan beberapa bangsa kepulauan yang tersebar di kepulauan Samudera Pasifik. Sementara itu, suku pendatang kebanyakan berasal dari daerah Buton, Makassar, Bugis, Cina dan Arab. Maluku juga memiliki ikatan tradisi dengan bangsa-bangsa kepulauan pasifik seperti bahasa, lagu daerah, makanan, perangkat peralatan rumah tangga dan alat musik.

Pendukung kebudayaan di Maluku terdiri dari ratusan suku, yang dapat diindikasikan dari pengguna bahasa lokal yang diketahui masih aktif dipergunakan sebanyak 117 dari jumlah bahasa lokal yang pernah ada. Meskipun masyarakat di daerah ini mencerminkan karakteristik yang multikultur, tetapi pada dasarnya mempunyai kesamaan nilai budaya sebagai representasi kolektif. Salah satunya adalah filosofi Siwalima yang selama ini telah melembaga sebagai cara pandang masyarakat tentang kehidupan bersama dalam kepelbagaian. Di dalam filosofi ini, terkandung berbagai pranata yang memiliki nilai umum dan dapat ditemukan di seluruh wilayah Maluku. (http://www.wacananusantara.org/sukubuton/diakses 26 Januari 2018. pukul 20.00).

Karyawan di Koperasi Serba Usaha Buru Jazirah Namlea terdiri atas laki-laki dan perempuan yang berasal dari suku Buton, Maluku, Jawa, dan Makassar. Dalam komunikasi sehari-hari mereka menggunakan bahasa Indonesia ragam resmi dan juga bahasa Melayu dialek Ambon. Namun ketika waktu istirahat untuk makan siang para karyawan berbaur menjadi satu sambil bercengkerama, berinteraksi dengan menggunakan bahasa daerah mereka masing-masing. Hal yang demikian inilah yang menyebabkan konflik kecil di antara mereka tetapi lama kelamaan karena mereka saling memahami bahasa tersebut.

Interaksi sosial adalah kegiatan yang mendapati dua orang atau lebih, saling menyesuaikan diri tentang kehidupan yang mereka miliki, sehingga dalam interaksi sosial diharuskan terdapat 
rasa saling memiliki atau peduli dalam setiap diri perilaku interaksi tersebut. Hal penting lain yang menjadi poin dalam interaksi adalah bahwa ketika seseorang menganggap yang lain sebagai objek, mesin, atau sebab akibat sebuah fenomena, maka tidak akan terjadi interaksi sosial. Interaksi sosial yang baik dapat mewujudkan hubungan yang baik dan harmonis di antara keduanya. Interaksi sosial yang baik dapat diwujudkan melalui sikap pengertian satu sama lain, saling menghargai dan saling menghormati, sehingga suatu kerja sama dapat dihasilkan dalam hubungan sosial antara pendatang dari suku Buton dan penduduk asli suku Maluku. Kerja sama yang berujung pada pencapaian suatu tujuan bersama.

A. Perilaku Berbahasa antara Karyawan Suku Buton dan Suku Maluku di Koperasi Serba Usaha Buru Jazirah Namlea.

1. Data Komunikasi antara Karyawan Suku Buton dan Suku Buru di Koperasi Serba Usaha Buru Jazirah Namlea berupa Kata:

Ketika waktu istirahat tepatnya pukul 13.00 para karyawan Koperasi Serba Usaha Buru Jazirah Namlea sedang menikmati makan siang. Sambil menikmati hidangan makan siang para karyawan tersebut berbincang-bincang. Biasanya mereka membicarakan seputar makanan dan minuman. Berikut data Komunikasi antara Karyawan Suku Buton dan Suku Buru di Koperasi Serba Usaha Buru Jazirah Namlea:

Data (1)

A : Sehabis makan siang saya akan inte (pergi) ke Savanajaya mungkin sebentar sore baru beta balik.

B : Pi ke Savanajaya deng sapa?

A : Sandirian sa.

Data (1) tersebut terjadi antara karyawan yang dinamakan Mantri atau lebih tepatnya bagian penagih (tukang batagih). Mantri tersebut memberitahukan kepada temannya bahwa sesudah makan siang dia (Mantri) akan pergi ke Savanajaya untuk menagih hutang. Bahasa yang dia pergunakan yaitu bahasa Melayu Dialek Ambon yang sudah tidak asing di telinga mereka tetapi dicapur dengan bahasa Buton dengan kata inte yang artinya pergi.

Data (2)

A : Besok hari Minggu beta pung rencana mau pi pasar

B : Mau beli baju ya?

A : Umbe (iya)

Dalam data (2), karyawan perempuan menyampaikan keinginannya kepada temannya bahwa dia akan pergi ke pasar, dan lawan bicaranya menebak dengan mengatakan apakah temannya pergi ke pasar untuk membeli baju? Percakapan mereka dengan menggunakan bahasa Melayu dialek Ambon dan diselingi dengan bahasa Buton dengan mengatakan umbe yang artinya iya.

Data (3)

A : Tolong ambilkan pena ndau (saya) yang jatuh di dekat kakimu itu.

B :Yang mana, ose seng tau kalau beta lagi makan?

A : Maaf ya.

Percakapan dalam data (3) tersebut, ada salah satu karyawan yang makan sambil memegang sebuah pena dan pena tersebut jatuh tepat didekat kaki temannya. Namun karena samasama sedang makan, maka teman yang disuruh mengambilkan pena tersebut mengatakan tidak bisa. Percakapan tersebut menggunakan bahasa Melayu Dialek Ambon dan juga berupa kata dari bahasa Buton dengan mengatakan $\boldsymbol{n d a u}$ yang artinya saya.

2. Data Komunikasi antara Karyawan Suku Buton dan Suku Buru di Koperasi Serba Usaha Buru Jazirah Namlea berupa Frasa: 
Karena sudah menjadi kebiasaan berkomunikasi dengan menggunakan bahasa daerah ketika berada di rumah, maka ketika berada di tempat kerja pun yang seharusnya menggunakan bahasa Indonesia ragam resmi tetap saja mereka menggunakan bahasa daerahnya masing-masing. Demikian seperti terlihat dalam data komunikasi antara karyawan suku Buton dan suku Maluku di Koperasi Serba Usaha Buru Jazirah Namlea berupa frasa:

Data (4).

A : Untuk makan sekarang beta mau bali sayoro mataha (sayur masak) saja.

B : Kalau saya ya biar saja makan apa yang ada.

A : Kalo beta iko-iko sa.

Data (4) tersebut terlihat masih membicarakan tentang makanan. Karena mungkin sayur di siang hari itu tidak sesuai dengan selera salah satu dari sekian banyak karyawan, sehingga karyawan tersebut berkata kepada temannya. Komunikasi antara karyawan dengan menggunakan bahasa Melayu Dialek Ambon dan juga bahasa Buton yang berupa frasa. Frasa dalam bahasa Buton tersebut ditAndai dengan mengatakan untuk makan sekarang beta mau bali sayoro mataha yang artinya (sayur masak).

\section{Data (5)}

A : Habis makan begini lha katong
makan buah, sedap.
B : Iya sekarang su musim po,o
motaha (mangga masak)
Percakapan dalam data (5) tersebut berupa frasa dari bahasa Buton yang mengatakan po,o motaha yang artinya (mangga masak). Dalam komunikasi tersebut antara karyawan suku Buton dan suku Maluku, bahasa yang mereka pergunakan sering kali dicampur aduk. Perilaku berbahasa seperti itulah yang terkadang membuat sesama rekannya tersinggung dikarenakan bahasa yang mereka pergunakan tidak bisa diketahui oleh suku lain. Namun karena sudah terbiasa mendengarkan bahasa Buton dan juga dialek Melayu Ambon maka lama kelamaan mereka juga memahaminya.

Data (6)

A. : Sekarang hari apa ya?

B. : Hari Rabu, memangnya ada apa?

A. : Pia alo (berapa hari) lagi gajian?

B. :Hahahaha sudah tidak ada uang kah?

Data (6) terjadi ketika sudah mendekati penerimaan gaji. Sambil menikmati makan siang, salah satu karyawan Koperasi Serba Usaha Buru Jazirah Namlea menanyakan perihal tentang tanggal karena dia mengetahui tidak lama lagi gaji karyawan akan dibagikan. Komunikasi tesebut berupa frasa dari bahasa Buton yang ditandai dengan mengatakan pia alo yang artinya (berapa hari).

\section{Data Komunikasi antara Karyawan} Suku Buton dan Suku Buru di Koperasi Serba Usaha Buru Jazirah Namlea berupa Kalimat:

Berikut ini data penelitian yang berupa kalimat yang terjadi komunikasi antara suku Buton dan suku Maluku di Koperasi Buru Jazirah Namlea ketika dalam waktu istirahat untuk makan siang.

Data (7)

$$
\begin{gathered}
\text { A : Teman, saya bisa pinjam uang } \\
100 \text { ribu saja? } \\
\text { B : Nda'u cia mane'e doe (saya } \\
\text { tidak punya uang). } \\
\text { Percakapan dalam data (7) }
\end{gathered}
$$
tersebut digunakan oleh suku Buton dengan sesamanya yaitu suku Buton. Komunikasi tersebut berupa kalimat dalam bahasa Buton dengan ditandai Nda'u cia mane'e doe yang artinya (saya tidak punya uang) agar pembicaraan mereka tidak diketahui 
oleh lain suku, karena menurutnya komunikasi tersebut rahasia. Adapun maksud dari komunikasi sesama suku tersebut dilakukan dengan secara sengaja karena ada maksud tertentu sehingga mereka bercakap dengan menggunakan bahasa sesama sukunya. supaya suku lainnya tidak mengetahui rahasia yang terkandung dalam kalimat tersebut.

\section{Data (8)}

A :Sudah waktunya untuk istirahat.

B : Sami inte ma'a yuk (ayo kita pergi makan).

A : Ayo beta su paling lapar kawan.

Percakapan dalam data (8) tersebut berupa kalimat dari bahasa Buton yang mengatakan Sami inte ma'a yuk yang artinya (ayo kita pergi makan). Dalam komunikasi tersebut antara karyawan suku Buton dan suku Maluku, bahasa yang mereka pergunakan sering kali dicampur aduk. Perilaku berbahasa seperti itulah yang terkadang membuat sesama rekannya tersinggung dikarenakan bahasa yang mereka pergunakan tidak bisa diketahui oleh suku lain. Namun karena sudah terbiasa mendengarkan bahasa Buton dan juga dialek Melayu Ambon maka lama kelamaan mereka juga memahaminya.

Data (9)

A : Iso'o meleru jam pia homorondo (kamu tadi malam tidur jam berapa)?

B : Memangnya mengapa kamu tanya itu?

A : Beta lihat kamu sudah berkalikali menguap.

Percakapan dalam data (9) tersebut karena sudah menjadi kebiasaan berkomunikasi dengan menggunakan bahasa daerah ketika berada di rumah, maka ketika berada di tempat kerjapun yang seharusnya menggunakan bahasa Indonesia ragam resmi tetap saja mereka menggunakan bahasa daerahnya masingmasing. Demikian seperti terlihat dalam data komunikasi antara karyawan suku Buton dan suku Buru di Koperasi Serba Usaha Buru Jazirah Namlea berupa kalimat dari bahasa Buton. Hal tersebut mereka lakukan karena memiliki tujuan tersendiri yaitu ketika percakapan ada sesuatu yang dirahasian supaya tidak diketahui oleh suku lain.

Berdasarkan hasil dan pembahasan dapat dikemukakan simpulan penelitian sebagai berikut:

1. Perilaku berbahasa antara karyawan suku Buton dan suku Buru di Koperasi Serba Usaha Buru Jazirah Namlea pada awalnya kurang begitu baik mengingat mereka saling berkomunikasi dengan menggunakan bahasa daerahnya masing-masing namun seiring dengan berjalannya waktu hal tersebut dapat diatasi sehingga terjalin kerjasama yang baik di antara suku tersebut.

2. Hambatan-hambatan yang terjadi dalam perilaku berbahasa antara karyawan suku Buton dan suku Maluku di Koperasi Serba Usaha Buru Jazirah Namlea pengaruh bahasa daerahnya masing-masing, antara kedua suku tersebut tidak bisa saling memahami karena kedua suku tersebut menggunakan bahasa daerahnya mereka masingmasing ketika berinteraksi.

3. Faktor-faktor yang menyebabkan terjadinya perilaku berbahasa antara karyawan suku Buton dan suku Buru di Koperasi Serba Usaha Buru Jazirah Namlea, karena sudah terbiasa menggunakan bahasa daerah ketika berada di rumah, dan ada sesuatu yang disembunyikan atau dirahasiakan yang tidak bisa diketahui oleh suku lain.

\section{PENUTUP}

Hasil penelitian ini belum mampu mendeskripsikan secara menyeluruh fenomena perilaku berbahasa antara suku Buton dan suku Buru yang terjadi dalam 
kegiatan waktu istirahat di kantor Koperasi Serba Usaha Buru Jazirah Namlea, Kecamatan Namlea, Kabupaten Buru, Maluku. Dengan keterbatasan ruang dan waktu yang dimiliki penulis sehingga data hanya menjangkau seputaran dalam satu kantor saja, sehingga data agak terbatas atau kekayaan jenis data agak terbatas. Bila dilihat dari segi faktor-faktor yang menyebabkan terjadinya perilaku berbahasa antara kryawan suku Buton dan suku Buru, secara teori hadirnya orang suku lain, dan berubahnya situasi sangat memungkinkan bila penelitian dilakukan di beberapa kantor.

Berdasarkan uraian di atas, bagi peneliti yang akan meneliti tentang perilaku berbahasa antara suku Buton dan suku Maluku, disarankan untuk meneliti selain dalam satu kantor, meneliti juga di beberapa kantor Koperasi Serba Usaha yang ada di Namlea.

\section{DAFTAR PUSTAKA}

Chaer, Abdul and Leoni Agustina. 2003. Sosiolinguistik Suatu Pengantar. Jakarta: Rineka Cipta.

Chaer, Abdul. 2004. Linguistik Umum. Jakarta: Rineka Cipta. Cangara, Hafied. 2012. Pengantar Ilmu Komunikasi. Jakarta : Rajagrafindo Persada.----------. 2003. DasarDasar Komunikasi Antarbudaya. Yogyakarta: Pustaka

Pelajar----------. $2007 . \quad$ DasarDasar Komunikasi Kesehatan. Yogyakarta : Pustaka Pelajar.

Juditha, Christiany. 2015. 'Stereotip dan Prasangka dalam Konflik Etnis Tionghoa dan Bugis Makassar'. Jurnal Ilmu Komunikasi Balai Besar Pengkajian dan Pengembangan Komunikasi dan Informatika. Volume 12, Nomor 1, Juni 2015: 87-104.

Liliweri, Alo. 2003. Dasar-Dasar Komunikasi Antar budaya. Yogyakarta :Pustaka Pelajar.
Mahsun. 2005. Metode Penelitian Bahasa. Edisi Revisi ed. Mataram: Rajawali Pers.

Mahsun. 2005. Metode Penelitian Bahasa. Tahapan, Strategi, dan Tekniknya. Depok: PT Grafindo Persada.

Moleong, Lexy J. 1990. Metodelogi Penelitian Kualitatif. Bandung: PT Remaja Rosdakarya.

Mulyana, 2005 Komunikasi Antar Budaya . Yogyakarta : Pustaka Pelajar.

---------. 2002. Makna Budaya Dalam Komunikasi Antarbudaya. Yogyakarta : LkiS Pelangi Aksara.

Nababan, P.W.J. 1991. Sosiolinguistik Suatu Pengantar. Jakarta: PT Gramedia.

Nababan. P.W.J. 1993. Sosiolinguistik: Suatu Pengantar. Jakarta: PT Gramedia Pustaka Utama.

Ohoiwutun, 1997. Dasar-Dasar Komunikasi Antar Budaya : Pustaka Pelajar.

Subroto. 2007. Penelitian Kuantitatif Kualitatif. Bandung:PT Remaja Rosdakarya.

Sugiyono. 2014. Metode Penelitian Kuantitatif Kualitatif, dan $R \& D$. Terbitan ke-21. Bandung: Alfabeta. 